\title{
Corrosion Properties of the Polypyrrole-molybdate Film Electro-polymerized on the AZ31 Mg Alloy
}

\author{
Wang Guixiang, Cao Nana, Zhang Xiaohong, Zhang Lili
}

Key Laboratory of Superlight Materials \& Surface Technology, Ministry of Education, Harbin Engineering University, Harbin 150001, China

\begin{abstract}
The polypyrrole (PPy) coating and polypyrrole-molybdate ( $\mathrm{PPy}-\mathrm{MoO}_{4}{ }^{2-}$ ) coating were electro-polymerized in sodium salicylate solution by cyclic voltammetry $(\mathrm{CV})$ on the AZ31 Mg alloy surface. Surface morphology of PPy coating and $\mathrm{PPy}_{-} \mathrm{MoO}_{4}{ }^{2-}$ coating on $\mathrm{Mg}$ alloy surface before and after being corrupted was observed by scanning electron microscopy (SEM). Attenuated total reflection-infrared (ATR-IR) spectra showed the characteristic ring stretching peaks of the PPy coating and PPy-MoO ${ }_{4}^{2-}$ coating, and also revealed the influence of $\mathrm{MoO}_{4}{ }^{2-}$ on the characteristic ring stretching peaks on PPy. The surface resistance was measured by four-point probe method. The open circuit potential (OCP), electrochemical impedance spectroscopy (EIS) and potentiodynamic polarization analyzed the corrosion resistance performance of PPy coating and $\mathrm{PPy}-\mathrm{MoO}_{4}{ }^{2-}$ coating on the $\mathrm{Mg}$ alloy surface in $3.5 \%$ $\mathrm{NaCl}$ solution immersing for $12 \mathrm{~h}$. The results show that the surface morphology of $\mathrm{PPy}-\mathrm{MoO}_{4}{ }^{2-}$ coating is compact. And the corrosion current density of PPy- $\mathrm{MoO}_{4}{ }^{2-}$ coating is lower three orders than that of the PPy coating. The PPy-MoO${ }_{4}{ }^{2-}$ coating on the $\mathrm{Mg}$ alloy surface has better corrosion resistance and smaller surface resistance than the PPy coating because of the existence of the molybdate ion.
\end{abstract}

Key words: polypyrrole-molybdate; cyclic voltammetry; magnesium alloy; corrosion

Magnesium is one of the most abundant metals on the earth and is the lightest in the practical metals ${ }^{[1]} . \mathrm{Mg}$ alloys play essential roles in vessels, aerospace, automotive, 3C and other fields, because of the outstanding performances: high specific strength, large elastic modulus and coefficient of thermal conductivity, good shock resistance and impact resistance, excellent machining performance and good organic and alkali corrosion resistance performance ${ }^{[2]}$. However, $\mathrm{Mg}$ alloys are easy to be corroded due to the low potential $(-2.73 \mathrm{~V})^{[3]}$. The corrosion resistance hinders its application, while appropriate treatment on the surface of $\mathrm{Mg}$ alloys can improve the corrosion resistance.

Chemical conversion coatings ${ }^{[4]}$, metal coatings ${ }^{[5]}$, anodic oxidation films ${ }^{[6]}$, ion implantation ${ }^{[7]}$, vapor deposition ${ }^{[8]}$ and organic membranes ${ }^{[9]}$ are the common surface treatment technology. The organic membranes are more common ${ }^{[10]}$. Recently, conductive polymers become a hot topic, as traditional organic membranes reduce the conductivity of the materials and application of $\mathrm{Mg}$ alloys in electronic communications and aerospace is increased ${ }^{[11]}$. Thus conductive polymer films meet the requirements of corrosion resistance, electromagnetic shielding and good adherence, which can well make $\mathrm{Mg}$ alloys be used in electronic communications and aerospace.

Polypyrrole (PPy), the typical conductive polymer has many advantages, such as convenient synthesis, good oxidation resistance, high conductivity, easy to film, soft, non-toxic ${ }^{[12]}$. PPy has always been used in biology, supper capacitor, anti-static materials, electromagnetic shielding materials, metal anticorrosion, etc. PPy film protects $\mathrm{Mg}$ alloys from corrosion by playing the roles of passivation and shielding ${ }^{[13]}$, which can increase self corrosion potential and reduce corrosion rate of $\mathrm{Mg}$ alloys. Chemical oxidation $^{[14]}$ and electric polymerization ${ }^{[15]}$ are the methods to synthesize PPy, in which chemical oxidation is suitable for the preparation of solid powdered polypyrrole while the

Received date: June 14, 2016

Foundation item: National Natural Science Foundation of China (51305090, 51479037); Natural Science Foundation of Heilongjiang (B201317)

Corresponding author: Wang Guixiang, Ph. D., Associate Professor, Key Laboratory of Superlight Materials \& Surface Technology, Ministry of Education, Harbin Engineering University, Harbin 150001, P. R. China, E-mail: wgx0357@126.com 
processing is difficult and the mechanical performance is poor. While the electric polymerization method adopts the three-electrode system under the control of electric field ${ }^{[16]}$. The monomer pyrrole (Py) is polymerized to form the polypyrrole film on the surface of $\mathrm{Mg}$ alloys. The method to polymerize polypyrrole is applied in the treatment of $\mathrm{Cu}^{[17]}$ and steel ${ }^{[18]}$ maturely, but fewer are used on the surface of active metals such as magnesium alloys.

Turhan $^{[19]}$ used cyclic voltammetry eletro-polymerized PPy film on AZ91D magnesium alloy surface in salicylate solution. The results showed that it had improved the corrosion resistance of $\mathrm{Mg}$ alloys. A. Srinivasan ${ }^{[3]}$ studied the properties of polypyrrole film on the AZ31 magnesium alloys. By characterization methods of ATR-IR, SEM, AFM and EIS, it revealed the films were rough and were similar to cauliflowers, and corrosion resistance had been improved. The yellow-black film was synthesized on AZ91 Mg alloys by Y. F. Jiang et al. ${ }^{[20]}$ This electric polymerization reaction occurred in alkaline solution. And different morphology had been formed by different pretreatment which affected potentiodynamic curves.

V. Karpakam ${ }^{[21]}$ reported the electro-synthesis of PANI$\mathrm{MoO}_{4}{ }^{2-}$ film on steel. The effect of $\mathrm{MoO}_{4}{ }^{2-}$ seemed to passivator and passive layer was formed before the electro-polymerization reaction occurred. In this paper, the electrolyte was sodium salicylate which included pyrrole and $\mathrm{MoO}_{4}{ }^{2-}$. The $\mathrm{PPy}-\mathrm{MoO}_{4}{ }^{2-}$ coating was carried out by cyclic voltammetry on AZ31 Mg alloys surface. The surface morphological was analyzed by scanning electron microscopy (SEM) and attenuated total reflection-infrared (ATR-IR) spectra. The corrosion resistance of PPy film and PPy- $\mathrm{MoO}_{4}{ }^{2-}$ was also discussed applying open circuit potential (OCP), electrochemical impedance spectroscopy (EIS) and potentiodynamic polarization.

\section{Experiment}

The composition and mass ratio of AZ31 Mg alloys have been shown in Table 1 . All the samples $(17 \mathrm{~mm} \times 17 \mathrm{~mm} \times 1$ $\mathrm{mm}$ ) made of AZ31 Mg alloys were ground with 320 \#, 800 \# and 1000 \# SiC grit emery paper and cleaned in 1:1 (vol\%) ethanol: acetone mixture for $10 \mathrm{~min}$ in ultrasonic bath. Then the samples were washed with distilled water. The electrolyte is a solution containing sodium salicylate. All cleaned samples were divided into two groups. One of them had been put into an electrolyte solution of $0.5 \mathrm{~mol} \cdot \mathrm{L}^{-1}$ sodium salicylate $+0.05 \mathrm{~mol} \cdot \mathrm{L}^{-1}$ pyrrole $(\mathrm{Py})$, while the electrolyte solution of the other group contained $0.5 \mathrm{~mol} \cdot \mathrm{L}^{-1}$ sodium salicylate $+0.05 \mathrm{~mol} \cdot \mathrm{L}^{-1} \mathrm{Py}+0.01 \mathrm{~mol} \cdot \mathrm{L}^{-1} \mathrm{MoO}_{4}{ }^{2-}$. The electro-polymerization reactions of the two groups were achieved in the recumbent electrolytic cell with three- electrode system in which AZ31 Mg alloy was used as working electrode, $\mathrm{Hg} / \mathrm{HgCl}_{2}$ was regarded as reference electrode and Pt wire was treated as counter electrode by cyclic voltammetry
Table 1 Composition and mass ratio of AZ31 Mg alloy (wt\%)

\begin{tabular}{cccccc}
\hline Element & $\mathrm{Al}$ & $\mathrm{Zn}$ & $\mathrm{Mn}$ & $\mathrm{Cu}$ & $\mathrm{Mg}$ \\
\hline Content & 2.83 & 0.8 & 0.37 & 0.002 & Bal. \\
\hline
\end{tabular}

$(\mathrm{CV})$ between $0.6 \mathrm{~V}$ and $2.0 \mathrm{~V}$ of sweeping potential at a scan rate of $7 \mathrm{mV} / \mathrm{s}$ for 10 cycles.

Scanning electron microscopy micrographs were obtained using JSM-6480A. Attenuated total reflection-infrared (ATR-IR) spectral analysis of the electrodeposited films on AZ31 Mg alloys was performed with a Perkin Elmer- Spectrum-two spec trophotometer. Surface resistance was measured by a four-point probe method.

The corrosion resistance performance of the uncoated and PPy and PPy- $\mathrm{MoO}_{4}{ }^{2-}$ coated alloys were evaluated through three methods with electrochemical workstation: open circuit potential, electrochemical impedance spectroscopy and potentiodynamic polarization. EIS over the frequency range from $10 \mathrm{kHz}$ to $0.1 \mathrm{~Hz}$ with $20 \mathrm{mV}$ amplitude, potentiodynamic polarization at the scan rate of $1 \mathrm{mV} / \mathrm{s}$ and open circuit potential varying with time were measured in $3.5 \% \mathrm{NaCl}$ for $12 \mathrm{~h}$ immersion using the above mentioned three-electrode system in which $\mathrm{AZ3} 1 \mathrm{Mg}$ alloy and coated alloys were used as working electrode (WE), $\mathrm{Hg} / \mathrm{HgCl}_{2}$ was regarded as reference electrode (RE) and Pt wire was treated as counter electrode (CE).

\section{Results and Discussion}

\subsection{Electrochemical polymerization}

The electrochemical polymerization of pyrrole (Py) and $\mathrm{Py}-\mathrm{MoO}_{4}{ }^{2-}$ is finished by cyclic voltammetry between 0 and $2.0 \mathrm{~V}$ of scan potential at $7 \mathrm{mV} / \mathrm{s}$ for 10 cycles in the solution of $0.5 \mathrm{~mol} \cdot \mathrm{L}^{-1}$ sodium salicylate $+0.05 \mathrm{~mol} \cdot \mathrm{L}^{-1} \mathrm{Py}$ and $0.5 \mathrm{~mol} \cdot \mathrm{L}^{-1}$ sodium salicylate $+0.05 \mathrm{~mol} \cdot \mathrm{L}^{-1} \mathrm{Py}+0.01$ $\mathrm{mol} \cdot \mathrm{L}^{-1} \mathrm{MoO}_{4}{ }^{2-}$, respectively. The first cycle and $\mathrm{CV}$ of polymerized PPy and PPy- $\mathrm{MoO}_{4}{ }^{2-}$ are shown in Fig.1.

No matter it is PPy or PPy- $\mathrm{MoO}_{4}{ }^{2-}$ coating on the $\mathrm{Mg}$ alloys, there is a peak between 0 and $0.5 \mathrm{~V}$ at the anodic sweep, which indicates the dissolving of the A31 Mg alloy ${ }^{[3]}$. The Fig. 1a shows the first cycle electro-synthesized PPy and PPy- $\mathrm{MoO}_{4}{ }^{2-}$ on the $\mathrm{Mg}$ alloy surface. The first anodic peak current of the PPy coating is lower than the PPy- $\mathrm{MoO}_{4}{ }^{2-}$ coating during the first cycle $\mathrm{CV}$, and hence the dissolution of $\mathrm{Mg}$ alloy of $\mathrm{PPy}-\mathrm{MoO}_{4}{ }^{2-}$ coating is larger than that of the PPy coating. Because the sodium salicylate solution contains $\mathrm{MoO}_{4}{ }^{2-}$, both the sodium salicylate and $\mathrm{MoO}_{4}{ }^{2-}$ can form a passivation film on the $\mathrm{Mg}$ alloy surface. Fig.1b reveals the CV of electro-polymerized PPy on the $\mathrm{Mg}$ alloy surface. The first anodic peak at about $0.2 \mathrm{~V}$ means the dissolution of $\mathrm{Mg}$ alloy and the second anodic peak at about $0.9 \mathrm{~V}$ indicates the oxidation of Py which polymerizes to form PPy film. At the beginning cycles of the $\mathrm{CV}$, the second peak at about $0.9 \mathrm{~V}$ is attributed to the 
oxidation of salicylate. Then the peak currents of subsequent cycles increase with increasing number of cycles, which indicates the formation of PPy. Under the electric field, Py monomer is activated to become the radical cation which is unstable and polymerizes with another radical cation to form dimer or trimer, and it gradually grows into PPy. A slight current increment at the end of each cycle confirms the polymer film growth. As can be seen in Fig.1c peaks at about 0.2 and $1.1 \mathrm{~V}$ appear which correspond to the dissolution of the $\mathrm{Mg}$ alloy and oxidation of Py. Comparing the $\mathrm{CV}$ of PPy and $\mathrm{PPy}-\mathrm{MoO}_{4}{ }^{2-}$ formation on the AZ31 Mg alloys surface, the oxidation potential of Py rises to $1.1 \mathrm{~V}$. The different oxidation potential of the two conditions probably is attributed to $\mathrm{MoO}_{4}{ }^{2-}$ in the sodium salicylate solution, which makes the oxidation potential of Py shift to positive due to the inhibitive nature of $\mathrm{MoO}_{4}{ }^{2-[21]}$.

\subsection{Surface morphological analysis}

Fig.2 reveals the surface morphology of the substrate, PPy coating and $\mathrm{PPy}-\mathrm{MoO}_{4}{ }^{2-}$ coating on the AZ31 Mg alloy surface using scanning electron microscopic in different
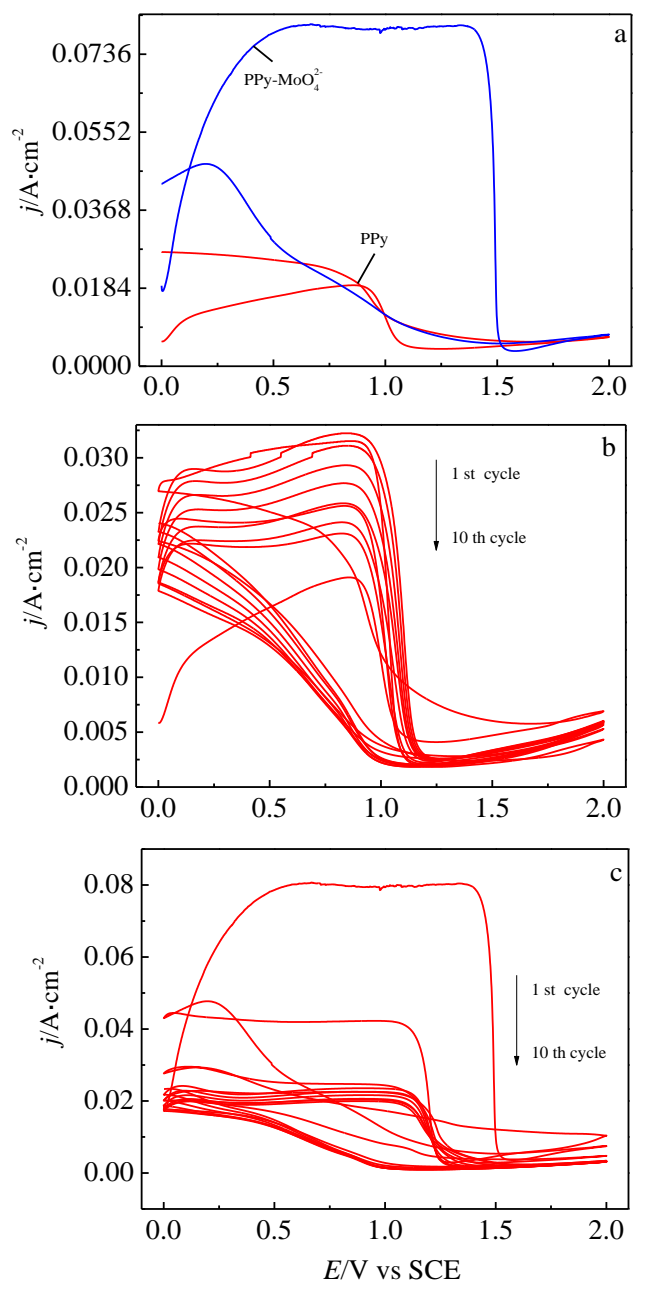

Fig. 1 First cycle electro-synthesized PPy and $\mathrm{PPy}_{-} \mathrm{MoO}_{4}{ }^{2-}$ (a), $\mathrm{CV}$ of electro-synthesized PPy (b), and CV of electrosynthesized $\mathrm{PPy}-\mathrm{MoO}_{4}{ }^{2-}$ (c) on AZ31 Mg alloys

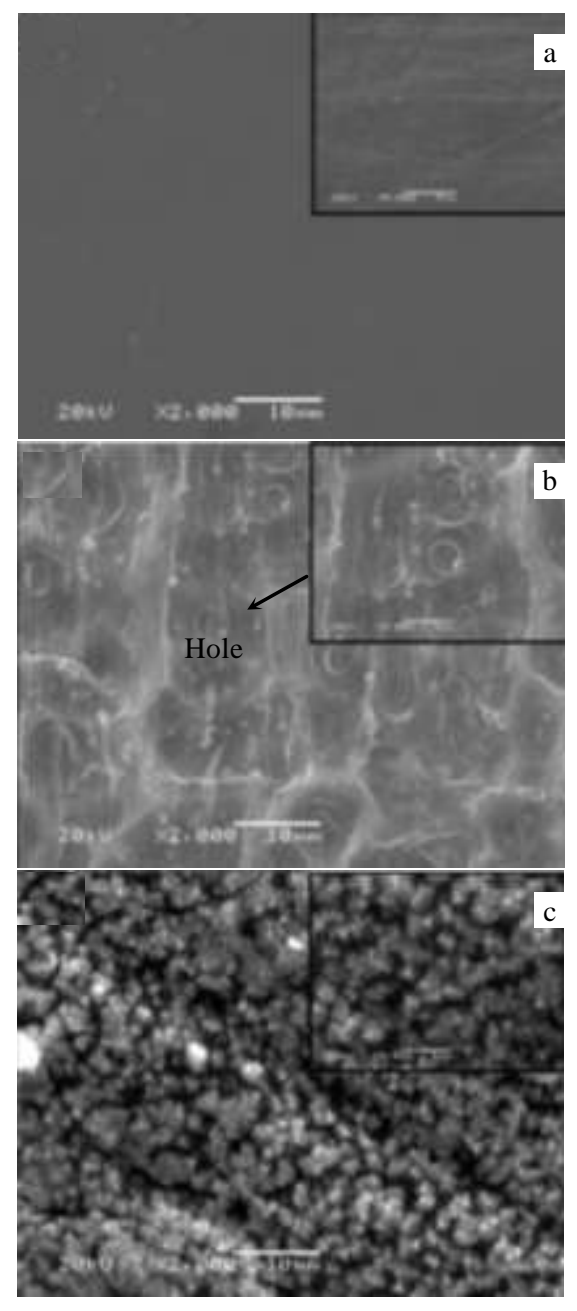

Fig. 2 SEM microstructures of bare AZ31 Mg alloy (a), PPy coating (b), and $\mathrm{PPy}-\mathrm{MoO}_{4}{ }^{2-}$ coating (c)

multiple scanning. Fig.2a which shows the surface morphologies of the $\mathrm{Mg}$ alloy substrate indicates that alloy surface is smooth. The surface morphology of PPy coating and $\mathrm{PPy}-\mathrm{MoO}_{4}{ }^{2-}$ coating on the alloy surface is shown in Fig.2b and Fig.2c, respectively. A marked difference is observed to contrast the Fig.2b and Fig.2c. The microstructure of PPy coating is porous, which increases probability that corrosive media enter the interior to corrode the alloy. However, this disadvantage doesn't exist in the $\mathrm{PPy}-\mathrm{MoO}_{4}{ }^{2-}$ coating in Fig.2c. The surface morphology of the $\mathrm{PPy}-\mathrm{MoO}_{4}{ }^{2-}$ coating is different from that of PPy coating. There are many like lump accumulations to achieve sealing effect, which can protect the alloy from corroding. The special microstructure may be formed due to interaction of $\mathrm{MoO}_{4}{ }^{2-}$ and polymer chains. The section scanning electron microscopy of the PPy coating and $\mathrm{PPy}_{-} \mathrm{MoO}_{4}{ }^{2-}$ coating on AZ31 Mg alloy is demonstrated in Fig. 3. The thickness of coatings is almost the same. Therefore, the $\mathrm{MoO}_{4}{ }^{2-}$ has little influence on the growth of coatings. 


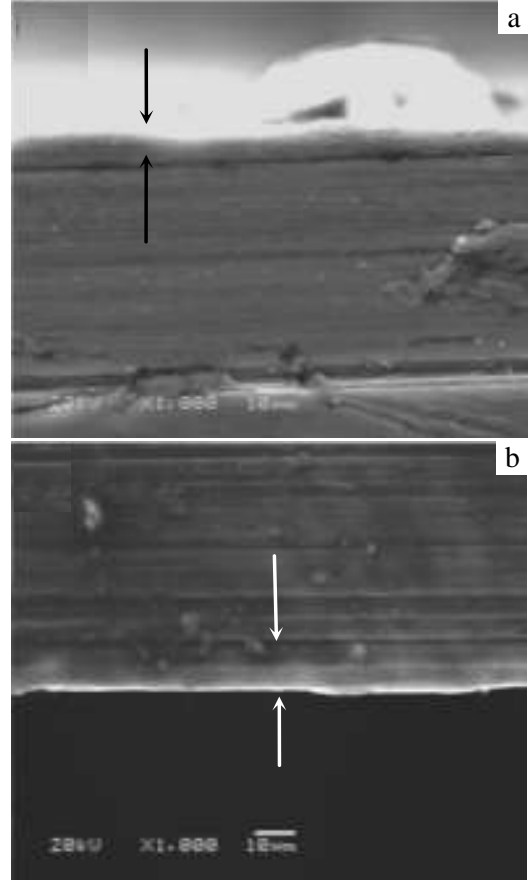

Fig. 3 Section SEM images of PPy coating (a) and $\mathrm{PPy}-\mathrm{MoO}_{4}{ }^{2-}$ coating (b)

\section{$2.3 \quad$ ATR-IR studies}

The PPy film and PPy-MoO ${ }_{4}^{2-}$ film formed on $\mathrm{AZ31} \mathrm{Mg}$ alloy surface by $\mathrm{CV}$ were analyzed using ATR-IR spectroscopic studies and the ATR-IR spectroscopy are shown in Fig.4 and Fig.5. The peak appears at about $1580 \mathrm{~cm}^{-1}$ which is attributed to the absorption peak of the $\mathrm{C}=\mathrm{C}$ stretching vibration. The peak around $1250 \mathrm{~cm}^{-1}$ is due to the stretching vibration of C-N. The characteristic peaks of PPy are detected around 1455, 1384, 1040, 930 and $755 \mathrm{~cm}^{-1}$. The peaks at

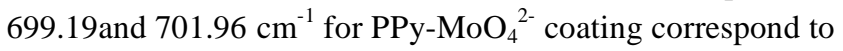
the stretching vibrations and bending of molybdate ${ }^{[21]}$. The surface resistance of PPy film is $4.3 \mathrm{~m} \Omega$, while the surface resistance of PPy- $\mathrm{MoO}_{4}{ }^{2-}$ has decreased to $3.6 \mathrm{~m} \Omega$.

\subsection{Corrosion studies}

\subsubsection{Electrochemical test}

The open circuit potential of PPy coating, $\mathrm{PPy}-\mathrm{MoO}_{4}{ }^{2-}$ coating and the uncoated $\mathrm{Mg}$ alloy were investigated periodically by immersing in $3.5 \% \mathrm{NaCl}$ for $12 \mathrm{~h}$. And the curves of open circuit potential (OCP) varying with time are shown in Fig.6. At first, the potential of the bare $\mathrm{Mg}$ alloy is about $-1.48 \mathrm{~V}$, then the potential is stable after $2 \mathrm{~h}$, while the stable potentials of the PPy coating and PPy- $\mathrm{MoO}_{4}{ }^{2-}$ coating are at about after $1 \mathrm{~h}$. It may be due to the quicker formation of corrosion product layer on the coated Mg alloys than that of the bare Mg alloy, which can be earlier to protect the Mg alloy from corrosion. The stale potential of PPy coating and PPy- $\mathrm{MoO}_{4}{ }^{2-}$ coating is about -1.461 and $-1.451 \mathrm{~V}$, respectively, which indicates the
PPy- $\mathrm{MoO}_{4}{ }^{2-}$ coating can resist the corrosive ion penetration through the film to the metal surface. Hence the $\mathrm{MoO}_{4}{ }^{2-}$ can provide double protection for the $\mathrm{Mg}$ alloy.

The electrochemical impedance of bare AZ31 Mg alloy and PPy and PPy- $\mathrm{MoO}_{4}{ }^{2-}$ coating obtained at the OCP after $12 \mathrm{~h}$ of immersion in $3.5 \% \mathrm{NaCl}$ solution are compared in Fig.7. The Nyquist shapes of uncoated, PPy coating and $\mathrm{PPy}-\mathrm{MoO}_{4}{ }^{2-}$ coating are similar, which consist of the capacitive reactance and inductive reactance. The capacitive reactance appear in the high frequency region manifests the control by the charge mass transfer process. The

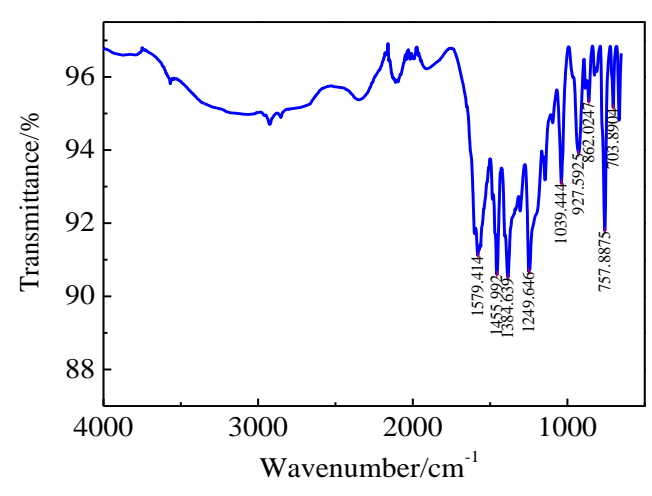

Fig. 4 ATR-IR spectrum for PPy coating

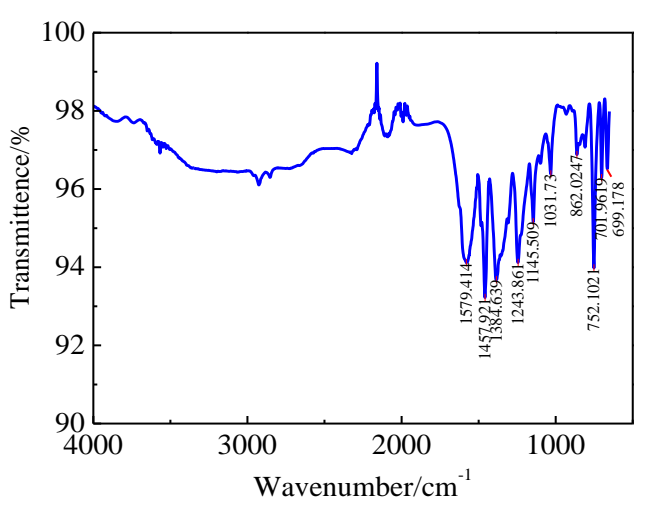

Fig.5 ATR-IR spectrum for PPy- $\mathrm{MoO}_{4}{ }^{2-}$ coating

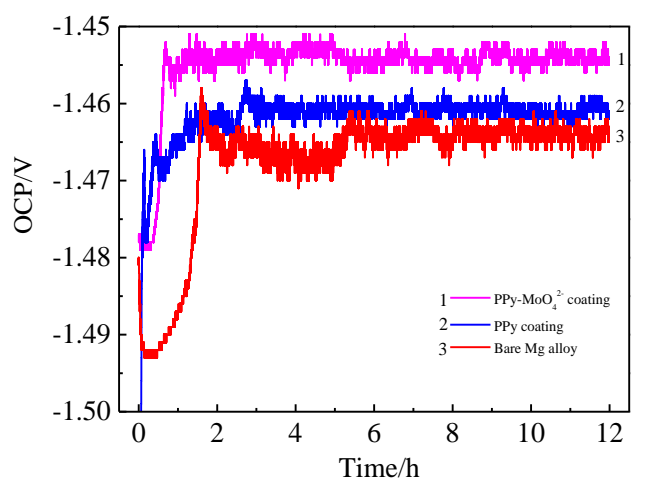

Fig. 6 OCP-time curves of PPy- $\mathrm{MoO}_{4}{ }^{2-}$ coating, PPy coating and bare $\mathrm{Mg}$ alloy 
higher the capacitive reactance arc radius is, the bigger the impendence value of coating is, so that it is difficult that the corrosion media enter to corrode the substrate. The impendence value of $\mathrm{PPy}-\mathrm{MoO}_{4}{ }^{2-}$ coating $\left(210 \Omega \cdot \mathrm{cm}^{2}\right)$ is bigger than that of the PPy coating $\left(187 \Omega \cdot \mathrm{cm}^{2}\right)$ whose impendence is bigger than that of the bare $\mathrm{Mg}$ alloy (137 $\Omega \cdot \mathrm{cm}^{2}$ ), hence the coating on the $\mathrm{Mg}$ alloy surface can improve the corrosion resistance performance, and the PPy- $\mathrm{MoO}_{4}{ }^{2-}$ coating on the AZ31 Mg alloy surface has the better corrosion resistance than PPy coating. The inductive reactance arc diameter of $\mathrm{PPy}-\mathrm{MoO}_{4}{ }^{2-}$ coating in the low frequency is slightly larger than others, which may be attributed to the decrease in the adsorbed corrosive ions from the $\mathrm{NaCl}$ solution.

Potentiodynamic polarization curves of the PPy coating, PPy- $\mathrm{MoO}_{4}{ }^{2-}$ coating and the bare $\mathrm{Mg}$ alloy after $12 \mathrm{~h}$ of immersion in $3.5 \% \mathrm{NaCl}$ solution are shown in Fig.8. In the polarization curves, it is clearly observed that the corrosion current density $\left(j_{\text {corr }}\right)$ of the $\mathrm{PPy}-\mathrm{MoO}_{4}{ }^{2-}$ coating $\left(9.896 \times 10^{-9}\right.$ $\left.\mathrm{A} \cdot \mathrm{cm}^{-2}\right)$ is lower than that of the PPy coating $\left(9.266 \times 10^{-6}\right.$ $\left.\mathrm{A} \cdot \mathrm{cm}^{-2}\right)$ and the substrate $\left(1.011 \times 10^{-5} \mathrm{~A} \cdot \mathrm{cm}^{-2}\right)$. While the $\mathrm{i}_{\text {corr }}$ of the PPy coating is close to that of the bare $\mathrm{Mg}$ alloy. These results indicate that the $\mathrm{PPy}-\mathrm{MoO}_{4}{ }^{2-}$ coating on the $\mathrm{Mg}$ alloy surface can offer enhanced corrosion resistance compared with the only PPy coating on the Mg alloy surface. The lower $j_{\text {corr }}$ of the $\mathrm{PPy}-\mathrm{MoO}_{4}{ }^{2-}$ coating may be attributed to the existence of $\mathrm{MoO}_{4}{ }^{2-}$ that offers better corrosion protection due to the formation of passive film along with the formation of $\mathrm{MoO}_{4}{ }^{2-}$ complex film.

\subsubsection{Surface morphological analysis after corrosion}

The surface morphological analysis after corrosion in $3.5 \% \mathrm{NaCl}$ for $12 \mathrm{~h}$ of PPy coating and $\mathrm{PPy}-\mathrm{MoO}_{4}{ }^{2-}$ coating on $\mathrm{Mg}$ alloy is shown in Fig.9. The corrosion pattern of the PPy coating and $\mathrm{PPy}-\mathrm{MoO}_{4}{ }^{2-}$ coating belongs to the total corrosion, which has a little danger coefficient compared with local corrosion. Corrosion of $\mathrm{PPy}-\mathrm{MoO}_{4}{ }^{2-}$ coating is uniform. However, there are many fractures when PPy

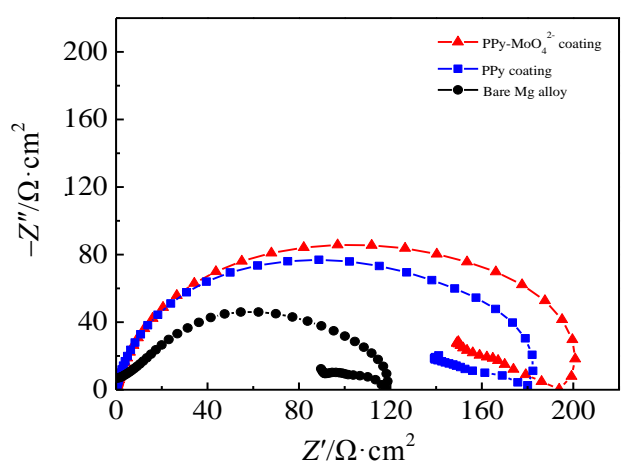

Fig.7 Nyquist plots of PPy- $\mathrm{MoO}_{4}{ }^{2-}$ coating, PPy coating and bare Mg alloy

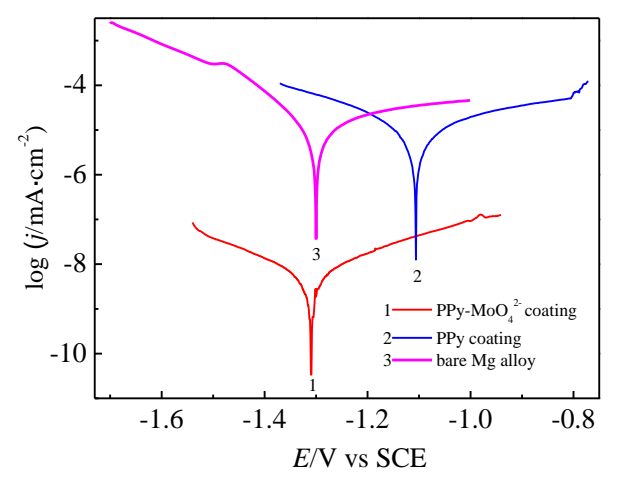

Fig. 8 Potentiodynamic polarization curves of $\mathrm{PPy}-\mathrm{MoO}_{4}{ }^{2-}$ coating, PPy coating and bare Mg alloy

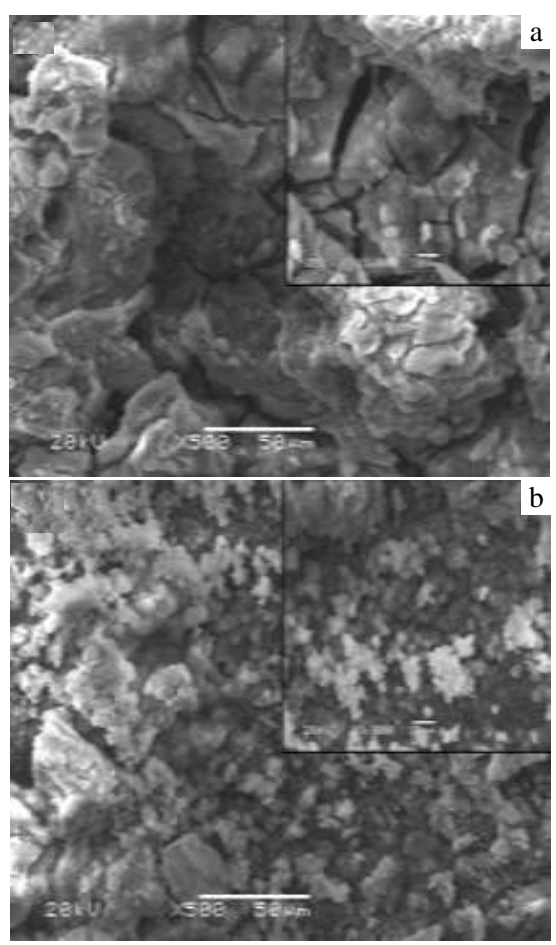

Fig. 9 SEM morphologies of PPy coating (a) and PPy- $\mathrm{MoO}_{4}{ }^{2-}$ coating (b) after corrosion

coating on the $\mathrm{Mg}$ alloy is corroded. And the microstructure of the PPy coating is looser than that of the $\mathrm{PPy}-\mathrm{MoO}_{4}{ }^{2-}$ coating. Moreover, the corrosion pit of the $\mathrm{PPy}-\mathrm{MoO}_{4}{ }^{2-}$ coating is regular.

\section{Conclusions}

1) The surface resistance of $\mathrm{PPy}-\mathrm{MoO}_{4}{ }^{2-}$ coating is smaller than that of the PPy, which can be applied in aerospace field. The electro-polymerized PPy coating on the AZ31 Mg alloy surface can offer the protection $\mathrm{Mg}$ alloy from corrosion, but the corrosion resistance performance is 
not better than the PPy- $\mathrm{MoO}_{4}{ }^{2-}$ coating.

2) $\mathrm{MoO}_{4}{ }^{2-}$ can form the $\mathrm{MoO}_{4}{ }^{2-}$ complex passive film on the $\mathrm{Mg}$ alloy surface before the Py polymerizes. Synergy between PPy and $\mathrm{MoO}_{4}{ }^{2-}$ makes the film surface morphology become compact, and prevents the iron-corrosion penetration to the $\mathrm{Mg}$ alloy surface, which can improve the corrosion resistance performance.

\section{References}

1 Hu R G, Zhang S, Bu J F et al. Progress in Organic Coatings[J], 2012, 73(2): 129

2 Yong Z Y, Zhu J, Qiu C et al. Applied Surface Science[J], 2008, 255(5): 1672

3 Srinivasan A, Ranjani P, Rajendran N. Electrochimica Acta[J], 2013, 88: 310

4 Yang X W, Wang G X, Dong G J et al. Journal of Alloys and Compounds[J], 2009, 487(1): 64

5 Shakoor R A, Kahraman R, Waware U S et al. Materials \& Design[J], 2014, 59: 421

6 Narayanan T, Park I S, Lee M H. Progress in Materials Science $[\mathrm{J}], 2014,60: 1$

7 Mao L H, Wang Y L, Wan Y Z et al. Rare Metal Materials and Engineering [J], 2010, 39(12): 2075

8 Wolfe R C, Shaw B A. Journal of Alloys and Compounds[J], 2007, 437(1): 157

$9 \mathrm{Wu}$ W, Lorenza P, Lina A et al. Rare Metal Materials and
Engineering $[\mathrm{J}], 2014,43(12): 2877$

10 Scharnagl N, Blawert C, Dietzel W. Surface and Coatings Technology[J], 2009, 203(10): 1423

11 Turhan M C, Weiser M, Killian M S et al. Synthetic Metals[J], 2011, 161(3): 360 .

12 Gopi D, Ramya S, Rajeswari D et al. Colloids and Surfaces B: Biointerfaces[J], 2013, 107: 130

13 Huang R, Chen M G, Lu X B. Acta Physico-Chimica Sinica[J], 2011, 27(1): 113

14 Bhattacharya A, Mukherjee D C, Gohil J M et al. Desalination $[\mathrm{J}], 2008,225(1): 366$

15 Flamini D O, Saidman S B. Corrosion Science[J], 2010, 52: 229.

16 Truong V T, Lai P K, Moore B T et al. Synthetic Metals[J], 2000, 110(1): 7

17 Lei Y H, Sheng N, Hyono A et al. Progress in Organic Coatings[J], 2014, 77(4): 774

18 Vera R, Schrebler R, Grez P et al. Progress in Organic Coatings[J], 2014, 77(4): 853

19 Turhan M C, Weiser M, Jha H et al. Electrochimica Acta[J], 2011, 56(15): 5347

20 Jiang Y F, Guo X W, Wei Y H et al. Synthetic Metals[J], 2003, 139(2): 335

21 Karpakam V, Kamaraj K, Sathiyanarayanan $\mathrm{S}$ et al. Electrochimica Acta[J], 2011, 56(5): 2165

\title{
AZ31 镁合金表面聚吡咯一钼酸盐膜的腐蚀性能
}

\author{
王桂香, 曹娜娜, 张晓红, 张丽丽 \\ (哈尔滨工程大学 超轻材料与表面技术教育部重点实验室, 黑龙江 哈尔滨 150001)
}

\begin{abstract}
摘 要: 在水杨酸钠溶液中采用循环伏安法在AZ31镁合金表面分别电聚合聚吡咯(PPy)膜和聚吡咯-钼酸根膜 $\left(\mathrm{PPy}^{-} \mathrm{MoO}_{4}{ }^{2-}\right)$ 。利用扫描电 子显微镜 ( $\mathrm{SEM}$ ) 观测 PPy膜和PPy- $\mathrm{MoO}_{4}{ }^{2-}$ 膜层腐蚀前后的表面形貌, 衰减全反射红外光谱 (ATR-IR) 反映了 $\mathrm{PPy}$ 膜和PPy-MoO${ }_{4}^{2-}$ 膜的 特征吸收峰, 研究了 $\mathrm{MoO}_{4}{ }^{2-}$ 的存在对PPy特征吸收峰的影响。使用四探针法测量薄膜的表面电阻; 采用开路电位 (OCP), 电化学交流阻 抗谱 (EIS) 和动电位极化曲线测试PPy膜和PPy- $\mathrm{MoO}_{4}{ }^{2}$ 膜在 $3.5 \% \mathrm{NaCl}$ 溶液中浸泡 $12 \mathrm{~h}$ 后的而腐蚀性能。结果显示, $\mathrm{PPy}^{-} \mathrm{MoO}_{4}{ }^{2-}$ 膜层更紧 凑, $\mathrm{PPy}-\mathrm{MoO}_{4}{ }^{2-}$ 膜层的腐蚀电流密度比 $\mathrm{PPy}$ 膜的低 3 个数量级。钼酸根的存在使得 $\mathrm{PPy}-\mathrm{MoO}_{4}{ }^{2-}$ 膜的表面电阻比PPy膜小, 且.PPy- $\mathrm{MoO}_{4}{ }^{2-}$ 膜的耐腐蚀性能较好。
\end{abstract}

关键词：聚吡咯-钿酸盐; 循环伏安; 镁合金; 腐蚀性

作者简介: 王桂香, 女, 1978 年生, 博士, 副教授, 哈尔滨工程大学超轻材料与表面技术教育部重点实验室, 黑龙江 哈尔滨 150001 , E-mail:wgx0357@126.com 